Ukrainian West: Culture and the Fate of Empire in Soviet Lviv. By WILLIAM JAY RIsCH, Pp. 374. Cambridge: Harvard University Press. Harvard Historical Studies, Volume 173. 2011. \$49.99. ISBN 9780674050013.

\title{
Soviet Lviv as a Shifting Phantasmagoria
}

In Ukrainian West: Culture and the Fate of Empire in Soviet Lviv, William Jay Risch provides a detailed and nuanced account of the transformation of the Western Ukrainian city of Lviv, known as L'vov, Lwów, and Lemberg. Risch describes the transformation of Lviv from a center of the Halych-Volyn Principality of the Crown of the Kingdom of Poland, to a multiethnic town in the Habsburg Empire, and finally, to a unique Western Ukrainian Soviet city in the post-war Soviet Union. The story of Lviv's transformation, he argues, does not follow a neat, linear path, but rather, is one complicated by shifting narratives, discourses, and allegiances. Despite Soviet state efforts to foster a 'generic Soviet Ukrainian identity', Risch argues, literary, linguistic, and cultural movements coalesced to shape a 'specific Western Ukrainian Soviet identity' of the city of Lviv (p. 4).

In the first section of the book, Risch outlines post-war Soviet politics and the transformation of Lviv as a 'Soviet city'. After the death of Stalin, the Soviet secret police chief, Lavrenty Beria, issued a report to encourage 'localism' and soon thereafter, the Communist Party of the Soviet Union passed a resolution calling for the election of 'locals'. In keeping with the resolution, the first Party secretary for Ukraine, L. G. Melnikov, an ethnic Russian, was forced to relinquish his position to an ethnic Ukrainian (35). Through official policy, the Soviet state co-opted the 'local' ...what? and was propagated as being closely aligned to Western Ukraine. However, during the period of Brezhnev's 'Thaw', integrationist policies spurred the arrival of as many as 45000 former nationalist guerrillas in Western Ukraine and this period of relative openness allowed for the formation of the Sixtiers Movement Shistdesiatnytstvo, which alongside other nationalist supporters, continued to oppose Sovietization (p. 24).

Risch provides in-depth accounts of the changes in demographics and the transformation of urban spaces that effectively asserted a 'Soviet' Western Ukrainian identity upon Lviv. Despite measures to de-Polonize Lviv, post-Stalin generations in the city viewed Soviet state imposition as foreign and the pre-Soviet era intelligentsia helped to solidify a local sense of Western Ukrainian identity, which did not hinge on constructed Soviet historical myths. Though host to these differing factions, Lviv did not foster a simple binary opposition between Soviet and antiSoviet allegiances. Rather, Lvivians were engaged in some forms of public Soviet life, while simultaneously maintaining private Ukrainian nationalist positions.

Lvivians accommodated public sphere Soviet state rhetoric while retaining ties to Galician perceptions of Ukrainian identity. The practice of accommodation by its residents allowed Lviv to become an arena in which public discourse was not a manifestation of private sentiment, but, rather, a performance. Risch describes this practice as 'preference falsification': publically suppressing private opinions for those deemed ideologically sound (pp. 4, 181). Through such accounts, Risch prodigiously renders simple binary oppositions problematic and, instead, carefully 
draws attention to the layered historical contexts, discourses, and practices that simultaneously shaped Lviv. Lviv, Risch writes, resembled a 'deceptive, shifting phantasmagoria...which took on multiple contradictory images...evading stable meaning' (p. 22).

To color his account of Lviv as a 'shifting phantasmagoria' (p. 22) in the second part of the book, Risch delves deep into the literary, linguistic, and cultural movements in the city. Risch poignantly describes how young Lvivians, particularly those who came of age after Stalin's death, challenged the culturally dominant conception of being Western Ukrainian. Members of the Writers' Union, and other authors alike, championed greater use of the Ukrainian language in public institutions and schools, while publications in the literary journal Zhovten' challenged Soviet 'official' histories (p. 120). Ukrainian poet Dmytro Pavlychko, once allied with the OPU nationalist underground movement, was a proponent of teaching the Ukrainian language and was credited with stemming Russification in Lviv (p. 122). Collective memory of pre-Soviet times, Risch argues, was also perpetuated through folk songs, artwork, literature, and other performances.

Yet, even the literary and cultural movements were not uniformly united in their Galician or nationalist Ukrainian claims. Rather, a cacophony of ambivalent and apathetic movements existed alongside the actively subversive, so while some were actively anti-Soviet, others were enveloped in the benign pleasures of football matches and pop music concerts. Throughout the book, Risch skilfully weaves together historical and cultural narratives into a broader account of the multi-faceted and complex interactions that together shaped the formation of Lviv. Through these rich accounts, collected over the course of a decade, Risch enables the reader to gain a sense of the complicated dynamism through which Lvivians shaped the city's idiosyncratic identity.

\section{STACY TOPOUZOIVA}

University of Oxford

This work is licensed under the Creative Commons Attribution-Non-commercial-Share-alike 2.0 UK: England \& Wales License. This license allows for redistribution and alteration, commercial and non-commercial, as long as credit is given to the author. To view a full copy of this license, visit: http://creativecommons.org/licenses/ or send a letter to Creative Commons, 444 Castro Street, Suite 900, Mountain View.

(C) School of Slavonic and East European Studies, University College London, 2014. 